\title{
CARTA DA EDITORA
}

Com esta edição concluímos um segundo ano de trabalho, de boas notícias com a melhor qualificação do Boletim do Museu Paraense Emílio Goeldi. Ciências Humanas em suas áreas precípuas - A1 no Qualis Capes, mas também de más notícias com recursos cada vez mais minguados para a Ciência brasileira. Ciência com letra maiúscula, fruto do trabalho e da competência de tantos, ainda que poucos para tudo o que se tem a fazer. Trabalhar ainda mais, mostrar o que fazem os que estudam e procuram entender o fenômeno da vida em suas mais variadas vertentes, essa é a luta permanente.

Com uma fluidez maior, a revista tem mantido sua periodicidade e ampliado canais de comunicação de seus conteúdos a públicos distintos. No contexto das ações de divulgação, a equipe da revista participou da Semana Nacional de ciência e Tecnologia, durante a programação do "Museu de Portas Abertas", programa educativo que alcança diversas audiências. Esta edição apresenta dossiê sobre patrimônio indígena e outros sete artigos, uma nota de pesquisa, um item na seção Memória e duas resenhas completam a edição. Linguística, História, Arqueologia e Museologia são o conteúdo completo da edição, resultado do pensamento acadêmico brasileiro que trava batalha diária para continuar a produzir. No dossiê "Patrimônio indígena e coleções etnográficas", pesquisadores do Museu Goeldi, do Museu Nacional de Etnologia de Leiden (NME) da Holanda, do Welt Museum¹ e do projeto "Museus da Amazônia em Rede (MAR)"2 discutem práticas colaborativas que promovem o reconhecimento do saber e da autoria dos objetos. As discussões revelam pontes, mostram travessias e encontros entre os donos do patrimônio original e as instituições que se transformaram em guardiãs e que apresentam tal patrimônio em suas dependências. Exercício essencial de respeito, reconhecimento e até mesmo de reparação, antropólogos, etnógrafos e museólogos se encontram com representantes de populações indígenas da Amazônia para, juntos, reconstituir a história contida em objetos hoje, compondo coleções etnográficas e sob a guarda de instituições em todo o mundo. De passado colonial ou não, estados-nação mantêm acervos formados a partir da coleta de objetos etnográficos ao longo de séculos. O patrimônio material se reveste de valor para a investigação científica, mas, sobretudo, de significado para as culturas donde foram criados.

São cinco os artigos do dossiê que refletem a cooperação e a possibilidade de inclusão dos autores em projetos expositivos. Com suas vozes e conhecimento dos significados que cada objeto em si carrega, membros de etnias Ka'apor, Warí, Kanoé, Makushi, Shipibo, Sataré-Mawé, Mebêngôkre-Kayapó e Baniwa dialogam com pesquisadores em exemplos concretos de etnomuseologia ou da museologia colaborativa.

\footnotetext{
Antigo Museu de Etnologia, reinaugurado em outubro de 2017.

2 A rede congrega quatro instituições da Amazônia oriental situadas no Brasil, na Guiana Francesa e no Suriname.
}

BELTRÃO, Jimena Felipe. Carta da Editora. Boletim do Museu Paraense Emílio Goeldi. Ciências Humanas, v. 12, n. 3, p. 701-702, set.-dez. 2017. DOI: http://dx.doi.org/10.1590/1981.81222017000300001. 
Dentre os demais artigos nesta edição, está "As classes verbais da língua Paresi (Aruák)", de Ana Paula Brandão, que apresenta os verbos e sua classificação na língua Paresi, falada por três mil indígenas no Mato Grosso.

A cartografia dos indígenas na Amazônia antes e durante a Era Pombalina. Entre mapas decorados e outros simétricos, de um e outro período, Alanna Souto discute as representações das populações nativas e no que tais formas de representar contribuíram para a desterritorialização e a reterritorialização em "Os indígenas na cartografia da América lusitana".

Helbert Medeiros Prado e Rui Murrieta discutem a investigação etnocientífica proposta por Tim Ingold no contexto de uma comunidade quilombola no Vale da Ribeira em "A experiência do conhecimento em Tim Ingold e as etnociências: reflexões a partir de um estudo de caso etnoecológico".

Trabalho etnográfico em terreiro de umbanda forneceu elementos para análise de como indivíduos tornam-se médiuns observando o engajamento, o contato e o contágio que estabelecem com as plantas. Essa é a proposta de "Jeitos, sujeitos e afetos: participação das plantas na composição de sujeitos umbandistas", de autoria de Pedro Crepaldi Carlessi.

Três artigos representam a Arqueologia nesta edição. Em "O muiraquitã da estearia da Boca do Rio, Santa Helena, Maranhão: estudo arqueológico, mineralógico e simbólico”, os autores - Alexandre Guida Navarro, Marcondes Lima da Costa, Abrahão Sanderson Nunes Fernandes Silva, Rômulo Simões Angélica, Suyanne Santos Rodrigues, João Costa Gouveia Neto - descrevem muiraquitã encontrado na estearia da Boca do Rio, no Maranhão, ao tempo que exploram possível cadeia operatória do artefato e analisam "redes regionais de interação comercial e simbólica" do dito objeto.

Em "Na sombra das pedras grandes: as indústrias líticas das ocupações pré-coloniais recentes da região de Diamantina, Minas Gerais, Brasil”, Andrei Isnardis trabalha com a disponibilidade de matérias-primas, as morfologias e a variabilidade artefatual para construir "entendimento articulado, sistêmico, de um conjunto de sítios...".

"História das pesquisas bioarqueológicas em Lagoa Santa, Minas Gerais", de Pedro Da- Glória, Walter Alves Neves e Mark Hubbe delineia 180 anos de pesquisa na região desde as primeiras intervenções do naturalista Peter Lund no século XIX até a atualidade e recomenda uma perspectiva interdisciplinar nos estudos sobre a região.

A dimensão educativa de um museu, o da Maré, no Rio de Janeiro e sua contribuição para a memória e a identidade de uma comunidade é o que Helena Maria Marques Araújo apresenta ao argumentar sobre o fortalecimento de grupos populares através da valorização e da ressignificação da história local em "Museu da Maré: entre educação, memórias e identidades".

A seção Memória deste número traz a história de Payaré, cacique Akrãtikatêjê, e sua luta na Justiça por mais de 30 anos para ver reparado erro histórico do Estado brasileiro, que negou a identidade indígena a ele e ao seu povo no contexto da construção da hidrelétrica de Tucuruí. De Mariana Guimarães: "A saga de Payaré Akrãtikatêjê frente ao Estado brasileiro no contexto da construção da hidrelétrica de Tucuruí".

Problemática regional, protagonismo amazônico e história ambiental marcam as resenhas de Felipe Jacinto, que analisou "Amazônia... A ira dos poderosos", de autoria de Ricardo Smith; e de Diogo de Carvalho Cabral, sobre a obra "A carne, a gordura e os ovos: colonização, caça e pesca na Amazônia", de Marlon Marcel de Fiori e Christian Fausto Moraes dos Santos.

Até 2018!

Jimena Felipe Beltrão

Editora Científica 